\title{
Breast Cancer Clinical Primary Tumor TNM Finding v7
}

National Cancer Institute

\section{Source}

National Cancer Institute. Breast Cancer Clinical Primary T umor TNM Finding v7. NCI

Thesaurus. Code C88365.

A clinical finding about one or more characteristics of breast cancer, following the rules of the TNM AJCC V7 classification system as they pertain to staging of the primary tumor. The TNM clinical and pathologic primary tumor classifications of breast cancer are the same, regardless of whether they are based on clinical and/or pathologic criteria. 